\title{
STAINING WITH AN ACRIDINE ORANGE DERIVATIVE FOR THE DETECTION OF MYCOPLASMAS IN CELL CULTURES
}

\author{
O. FISCHER and Dagmar ZENDULKOVÁ
}

Veterinary Research Institute, 62132 Brno

Received October 26, 1992

\begin{abstract}
- Fischer O., Dagmar Zendulková: Staining With an Acridine Orange Derivative for the Detection of Mycoplasmas in Cell Cultures. Acta vet. Brno, 62, 1993: 49-53.

24 cell cultures were examined for the presence of mycoplasmas by fluorescence methods using 3-amino-6-methoxy-9-(2-hydroxyethylamino) acridine (AMHA) or bisbenzimide 33258 (Hoechst), and by culture in liquid media containing glucose or arginine and, under anaerobic conditions, on solid media. Mycoplasmas were detected in 17.9, 25.5 and 28.6 per cent of the cultures by staining with AMHA, staining bisbenzimide and by culture, respectively. The differences in sensitivities of the methods were not significant. Disadvantages of staining with AMHA were discussed.
\end{abstract}

\section{Fluorescence, staining, mycoplasma contamination}

Detection of mycoplasmas in cell cultures by fluorescence methods is based on the visualization of nucleic acids of mycoplasmas. The stains used include bisbenzimide (Chen 1977), olivomycin (Mikhailova et al. 1982) and 4'-6-diamidine-2-fenylindol (DAPI) (Russell et al. 1975). Jayat-Vignoles et al. (1990) described the use of a new acridine orange derivative - 3-amino-6-methoxy-9-(2-hydroxyethylamino) acridine (AMHA) - for this purpose.

In our laboratory, checks of the presence of mycoplasmas in cell cultures have been performed using the culture and the bisbenzimide 33258 (Hoechst) methods. Staining with AMHA was examined to extend the set of the detection methods, and the results were compared with those of the bisbenzimide and the culture methods.

\section{Materials and Methods}

The examined cell cultures (Table 1) came from the cell culture bank and other laboratories of the Veterinary Research Institute, Brno, as well as from laboratories outside the institute. Altogether 117 samples of 24 cell cultures, of which 23 were monolayer cultures and 1 (myeloma line FO) was a semisuspension culture, were examined.

The monolayers were grown in a closed system in Mueller, Legroux or Roux flasks in Eagle's Minimal Essential Medium supplemented with 10 per cent of fetal calf serum, penicillin (100 I.U. per $1 \mathrm{ml})$ and streptomycin $(100 \mu \mathrm{g}$ per $1 \mathrm{ml})$.

The cells were released enzymatically before re-seeding them by a solution containing 0.1 to 0.2 per cent of chymotrypsin or trypsin, and 0.02 per cent of versene.

The propagation of hepatoma cell lines was described by Hankinson (1979).

Before the examination by fluorescence, the cells were inoculated into test tubes containing pieces of slides $(5 \times 20 \mathrm{~mm})$ and $2 \mathrm{ml}$ of growth medium, and incubated at $37^{\circ} \mathrm{C}$.

A cell suspension density was chosen that would not produce a complete monolayer during 3 to 5 days of growth. The propagation of the semi-suspension myeloma cell line FO and its co-culture with Vero cells, used as an indicator, were described earlier (Fischer et al. 1991).

The acridine orange derivative AMHA was kindly supplied by Prof. $\mathrm{H}$. W. Zimmermann from the Institut für physikalische Chemie der Universität in Freiburg, FRG.

Stock solution of AMHA in distilled water $(10 \mathrm{mM})$ was stored in the dark at $+4{ }^{\circ} \mathrm{C}$ and working solutions were prepared before staining. The concentration $5 \mu \mathrm{M}$ and an exposure period 
of 15 minutes, as recomməupəp q $\Lambda$ Jayat-Vignoles et al. (1990), were used in pilot experiments, but the fluorescence was very weak only. Therefore, the concentration was increased to $10 \mu \mathrm{M}$ and the exposure period prolonged to 30 minutes.

The slides with cell islets were rinsed with isotonic phosphate buffer PBS (pH 7.2), stained with $10 \mu \mathrm{M}$ AMHA for 30 minutes, washed with PBS for another 15 minutes, mounted into glycerol buffer (pH 5.5) (Machatková et al. 1986), and viewed in a Zeiss fluorescence microscope at a magnification of $252 \times$.

Staining with bisbenzimide 33258 (Hoechst) was performed using a modification (Machatková et al. 1986) of Chen's (1977) method. The incomplete cell monolayers were rinsed with PBS (pH 6.5 to 6.8) and the cells were fixed with methanol for 15 minutes. After air-drying, the cells were stained with 0.001 per cent solution of bisbenzimide 33258 in methanol for 10 minutes, rinsed with distilled water, mounted into glycerol buffer ( $\mathrm{pH}$ 5.5) and viewed as described for the AMHA-stained cultures.

The examination by culture was preceded by at least 3 passages in a streptomycin-free medium. Both liquid media, containing glucose or arginine, and solid media were used. The culture on solid media passed under anaerobic conditions (Jurmanová and Machatková 1986; Jurmanová et al. 1990).

The results were processed by the Student's t-test.

\section{Results}

Mycoplasmas were demonstrated in 13 of the 24 cell cultures (Table 1). 17.9, 25.5 and 28.6 per cent of the samples were positive by the AMHA, bisbenzimide and culture methods, respectively. The differences in sensitivities of the methods were not significant $(P>0.05)$.

Discolouration of liquid media, resulting from the fermentation of glucose or arginine, became evident within 10 to 14 days of incubation of mycoplasma-infected cell cultures.

Table 1

Comparison of staining and culture methods for detection of mycoplasmas in cell cultures

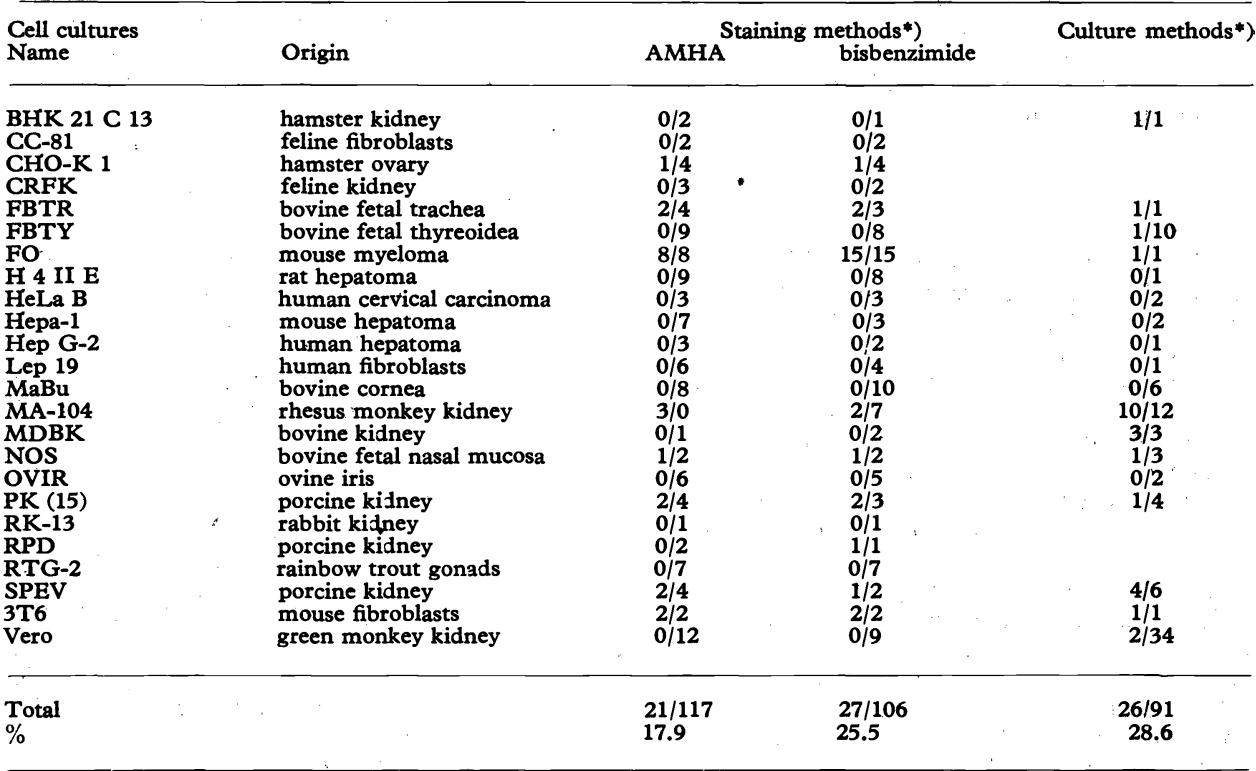

*) Number of positive and total number of samples are given in the numerator and denominator, respectively. 
Visible colonies of mycoplasmas developed on solid media after 14 days of incubation under anaerobic conditions.

Staining with bisbenzimide or AMHA visualized mycoplasmas as minute, intensively fluorescent, yellow-green particles in the vicinity of large, intensively fluorescent, yellow-green nuclei (Fig. 2 and 4); only fluorescent cell nuclei were observed in mycoplasma-free cell cultures (Fig. 1 and 3).

The two staining methods differed in their intensities and persistences of fluorescence.

While nucleoli were clearly distinguishable in the fluorescent nuclei, the background was dark and cytoplasma was stained in sporadic cells and only very weakly in cell cultures stained with bisbenzimide, no nucleoli were recognisable and the background and cytoplasma were bright yellow-green in those stained with AMHA (Fig. 1 to 4 ).

The fluorescence persisted longer in the bisbenzimide-stained than in the AMHA-stained cell cultures.

\section{Discussion}

It follows from the description of the two fluorescence methods that staining with AMHA is more time-consuming than that with bisbenzimide ( 45 vs. 25 minutes).

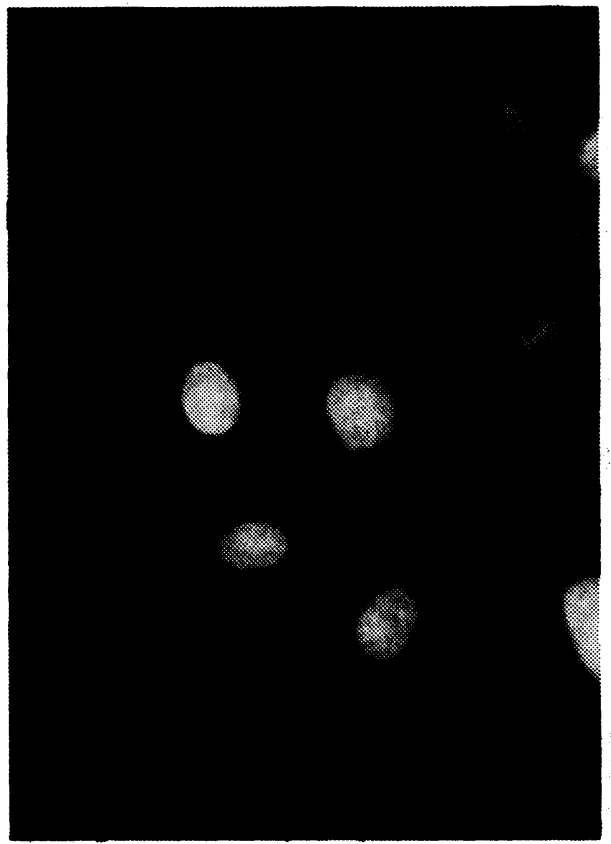

Fig. 1: Mycoplasma-free Vero cells. Stained with bisbenzimide.

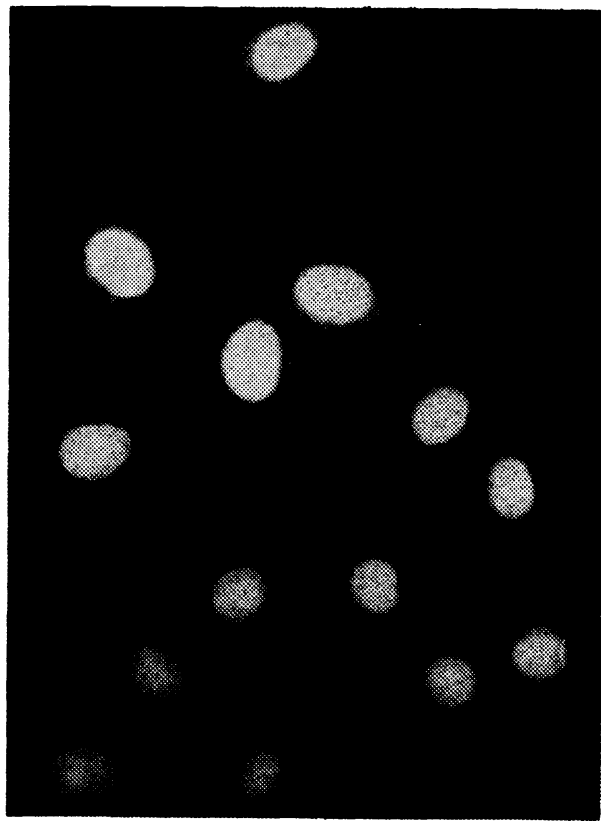

Fig. 2: Mycoplasma-infected Vero cells. Stained with bisbenzimide. 
Regarding the shorter persistence of fluorescence of AMHA-stained cultures, Jayat-Vignoles et al. (1990) recommended to use an anti-fading solution. In our experiments this step was replaced by mounting of the preparations into glycerol buffer as described by Machatková et al. (1986). A more intensive and persistent staining was achieved by increasing the concentration of AMHA from 5 to $10 \mu \mathrm{M}$ and prolonging the exposure period from 15 to $30 \mathrm{mi}$ nutes.

While only nuclei and nucleoli are stained by bisbenzimide, and the fluorescence of cytoplasma, if present, is regarded as an unwanted artifact (Fischer et al. 1991), cytoplasm of all cells is stained by AMHA. Jayat-Vignoles et al. (1990) explained this phenomenon by the ability of AMHA to stain both nuclear DNA and cytoplasmatic RNA. Minute fluorescent particles can be overlooked easily on a bright background and therefore the fluorescence of cytoplasm is unwanted. Staining with bisbenzimide is apparently more suitable, because the background is dark and the minute mycoplasmas can be recognized easily. This is important especially in weakly contaminated cell cultures.

Regarding the difficulties associated with the detection of mycoplasmas in cell cultures, parallel use of at least two methods should be preferred to relying upon the results of any single method.

No significant differences in sensivities were demonstrated between the two staining methods. However, AMHA staining had more disadvantages than staining with bisbenzimide.

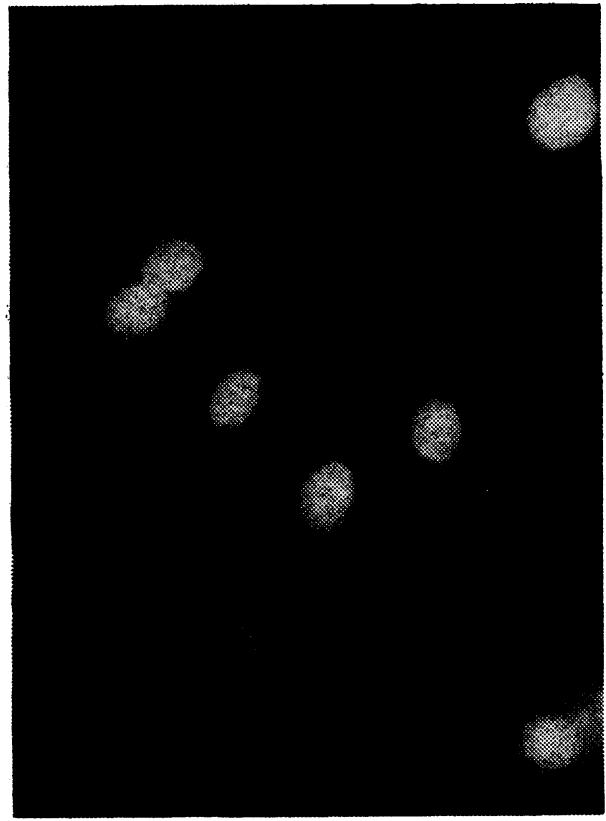

Fig. 3: Mycoplasma-free Vero cells. Stained with AMHA.

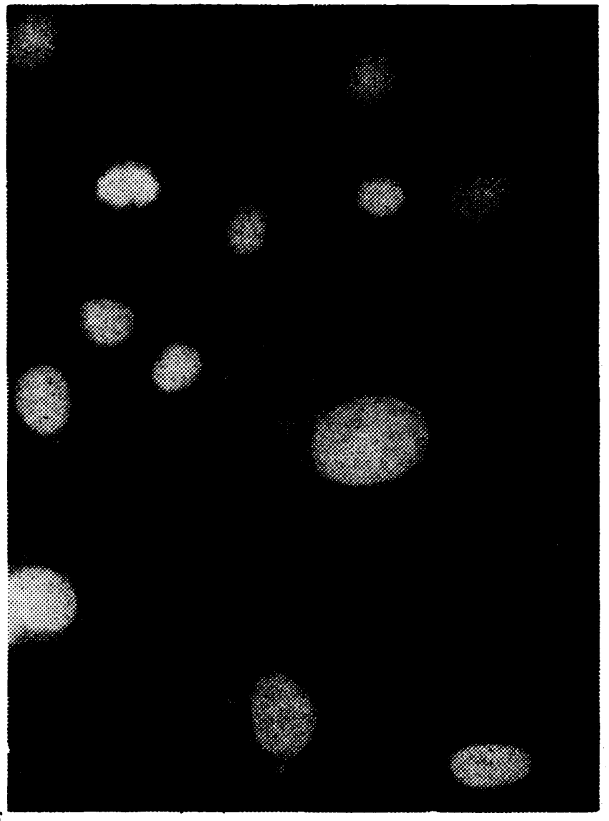

Fig. 4: Mycoplasma-infected Vero cells. Stained with AMHA. $\times 252$. 
Použití derivátu akridinové oranže $\mathrm{k}$ detekci mykoplazmat $\mathbf{v}$ buněčných kulturách

Ve 24 buněčných kulturách byla zjištována přitomnost mykoplazmat fluorescenčními metodami s barvením 3-amino-6-methoxy-9-(2-hydrexyethylamino) akridinem (AMHA) nebo bisbenzimidem 33258 (Hoechst) a kultivací v tekutých mediích s glukózou nebo argininem a kultivací na pevných půdách $\mathrm{v}$ anaerobních podmínkách.

Barvením AMHA byla mykoplazmata zjištěna v 17,9 \% kultur, barvením bisbenzimidem v $25,5 \%$ kultur a kultivačními metodami v $28,6 \%$ kultur.

Rozdíly v citlivosti použitých metod nebyly statisticky významné.

\section{Применение производной акридинового оранжа для определения микоппазмы в клеточных күльтүрах}

В 24 клеточных культурах определяли наличие микоплазмы флюоресцентными методами с окраской 3-амино-6-метокси-9-(2-гидроксиэтиламино) акридином (АМНА) или бисбензимидом 33258 (Хэхст) күльтивированием В жидких средах с глюкозой или аргинином и культивированием на прочных почвах в анаэробных условиях.

Окраской АМНА была микоплазма выявлена в $17,9 \%$ культур, окраской бисбензимидом - В 25,5 \% культур и методами культивирования - в $28,6 \%$ күльтур.

Разница чувствительности примененных методов не отличалась статистической значимостью.

\section{Acknowledgements}

The authors wish to thank Prof. H. W. Zimmermann for the kind supply of AMHA and apprceiate skilled technical assistance of Mrs. Alena Farníková.

\section{References}

CHEN, T. R.: In situ detection of mycoplasma contamination in cell cultures by fluorescent Hoechst 33258 stain. Exp. Cell Res., 104, 1977: 255-262

FISCHER, O.-GRANÁTOVA, M.-HẢJKOVÁ, M.-NEVORÁNKOVA, Z.-JURMANOVA, K.: Detection of mycoplasmas in cultures of myeloma cell lines and hybridomas by fluorescence method using Vero cells as indicators. Acta vet. Brno, 60, 1991: 41-49

HANKINSON, O.: Single-step selection of clones of a mouse hepatoma line deficient in aryl hydrocarbon hydroxylase. Proc. Natl. Acad. Sci. U.S.A., 76, 1979: 373-376

JAYAT-VIGNOLES, C. - RATINAUD, M. - JULIEN, R.: 3-amino-6-methoxy-9-(2-hydroxyethylamino) acridine: a new fluorescent dye to detect mycoplasma contamination in cell cultures. Cytotechnology, 4, 1990: 191-194

JURMANOVÁ, K.-HAJJKOVÁ, M.-FISCHER, O.: Detection of mycoplasmas in cell cultures. Zbl. Bakt., Suppl. 20, 1990: 947-948

JURMANOVA, K.-MACHATKOVÁ, M.: Detection of mycoplasmas in cell cultures and biologicals. Arch. exp. Vet. Med., 40, 1986: 136-141

MACHATKOVÁ, M.-JURMANOVÁ, K.-HAMPL, J.-ŠNEJDAR, V.: Spontánni infekce buněčných kultur mykoplazmaty a její detekce fluorescenční metodou. Vet. Med. Praha, 31, 1986: $447-485$

MIKHAILOVA, G. P. - NOVOKHATSKYI, A. S. - RODOVA, M. A.: Novyi sposob vyyavleniya mikoplazm v perevivaemykh kulturakh kletok. Vopr. Virusol., 27, 1982: 759-761

RUSSEL, W. C. - NEWMAN, C. - WILLIAMSON, D. H.: A simple cytochemical technique for demonstration of DNA in cells infected with mycoplasmas and viruses. Nature (London), 253, 1975: $461-462$ 